\title{
Competence to regulate streaming in Brazil: an analysis of the roles of the Ministry of Science, Innovation, Technology and Communication, Anatel and Ancine
}

\section{A competência para regular os serviços de streaming: uma análise da atuação do Ministério da Ciência, Inovação, Tecnologia e Comunicação, da Anatel e da Ancine}

\author{
Lucas Bossoni Saikali* \\ Universidade Federal do Paraná (Curitiba, Paraná, Brasil) \\ saikalilucas@gmail.com \\ https://orcid.org/0000-0001-6589-4269
}

Recebido/Received: 05.05.2021/ May 5 $5^{\text {th }}, 2021$

Aprovado/Approved: $12.08 .2021 /$ August $12^{\text {th }}, 2021$

\begin{abstract}
Technological development has extremely useful facets for everyday life since disruptive innovations are increasingly present in society. In this current scenario, the State's intervention in the economy is increasingly difficult. The objective of this research is to investigate the regulatory role of the Executive Power and regulatory agencies regarding streaming technologies. To do so, initially, the paper investigates the definition of streaming services, analyzing their legal adequacy according to Brazilian legislation. Subsequently, the regulatory competence of the Ministry of Science, Technology, Innovation and Communication, the National Telecommunications Agency, and the National Cinema Agency in
\end{abstract}

Como citar este artigo/How to cite this article: SAIKALI, Lucas Bossoni. Competence to regulate streaming in Brazil: an analysis of the roles of the Ministry of Science, Innovation, Technology and Communication, Anatel and Ancine. International Journal of Digital Law, Belo Horizonte, ano 2, n. 2, p. 119-135, maio/ago. 2021. DOI: 10.5380/IJDL.saikali.v.2.n.2

* Master of Law at Pontifical Catholic University of Paraná (Curitiba, Paraná, Brazil). PhD Student at the Federal University of Paraná (Curitiba, Paraná, Brazil). Member of the Center of Constitutional Investigations (NINCUFPR) and of the Research Group on Social Administrative Law (REDAS). Assistant editor of the International Journal of Digital Law. E-mail: saikalilucas@gmail.com 
relation to new technologies for dispersion of audiovisual content is analyzed. In the end, it is concluded that it is the responsibility of MCTIC to be the granting power of broadcasting services, not interfering in streaming services. Anatel is responsible for regulating the conditions and the relationship between streaming and telecommunications service providers, in this case, the internet, as well as assuring them the right to use the internet infrastructure. Ancine is responsible for acting with the objective of promoting, regulating, and supervising the cinematographic and videophonographic industry in the various market segments. The research methodology used is the hypothetical-deductive and research technique is indirect documentation.

Keywords: Disruptive innovation. Streaming. Regulation. Executive Branch. Anatel. Ancine.

Resumo: O desenvolvimento tecnológico apresenta facetas úteis para o cotidiano, pois as inovações disruptivas estão presentes na sociedade. No cenário atual, a intervenção do Estado na economia é cada vez mais difícil. O objetivo desta pesquisa é investigar o papel regulador do Poder Executivo e dos órgãos reguladores em relação às tecnologias de streaming. Inicialmente, o artigo investiga a definição de serviços de streaming, analisando sua adequação jurídica à legislação brasileira. Posteriormente, é analisada a competência regulatória do Ministério da Ciência, Tecnologia, Inovação e Comunicação, da Agência Nacional de Telecomunicações e da Agência Nacional do Cinema em relação às novas tecnologias de dispersão de conteúdos audiovisuais. Conclui-se que cabe ao MCTIC ser o poder concedente dos serviços de radiodifusão, não interferindo nos serviços de streaming. A Anatel é responsável por regular as condições e a relação entre as operadoras de streaming e de telecomunicações, neste caso, a internet, bem como assegurar-lhes o direito de uso da infraestrutura de internet. A Ancine é responsável por atuar com o objetivo de promover, regular e fiscalizar a indústria cinematográfica e videofonográfica nos diversos segmentos de mercado. A metodologia de pesquisa é a hipotético-dedutiva e a técnica de pesquisa é a documentação indireta.

Palavras-chave: Inovações disruptivas. Streaming. Regulação. Poder Executivo. Anatel. Ancine.

Contents: 1 Introduction - $\mathbf{2}$ The definition and legal category of streaming services in Brazil - $\mathbf{3}$ The regulatory power of the Ministry of Science, Innovation, Technology and Communication $\mathbf{- 4}$ The competence of the National Telecommunications Agency - $\mathbf{5}$ The sectorial role of the Nacional Cinema Agency - 6 Conclusion - References

\section{Introduction}

The ideas of complexity and contingency are of great relevance in the work of sociologist Niklas Luhmann. ${ }^{1}$ According to the author, the first is understood as the excess of possibilities, alternatives, and variations in the modern world, among which it is up to the individual to choose. The second is the unpredictability of the outcome of a decision, due to the risks assumed with the choice. The indeterminate future described by Luhmann is increasingly evident with the progress of the 21st century. One reason for the uncertainty of a complex and contingent modern world that surrounds people's daily lives is technological advancement. In the blink of an eye, a device becomes outdated. Overnight, notebooks lose space to laptops and

1 LUHMANN, Niklas. Introdução à teoria dos sistemas. 3. ed. Petrópolis: Vozes, 2009; LUHMANN, Niklas. Sistemas Sociales: Lineamentos para una teoría general. Tradução: Silvia Pappe e Brunhilde Erker. México: Anthropos Editorial/Universidad Iberoamericana, 1998; LUHMANN, Niklas. Sociologia do Direito. Vol. I. Tradução: Gustavo Bayer. Rio de Janeiro: Tempo Brasileiro, 1983. 
new versions of a smartphone are created, which causes the constant loss of value of old devices in a market marked by innovations.

Keeping up with technology is no easy task. For the State, this exercise is even more difficult. With the ease of using the internet, private companies started to provide services similar to public services provided by the Public Administration, directly or indirectly. Uber offered competition to taxi services. WhatsApp appeared as a challenge for the telecommunications sectors. The examples vary, which highlights the reality of new technologies that overlap traditional services regulated by the Public Administration.

In the present study, the focus is on another service provided through the world wide web, the content diffusion service via streaming. The logic of this service is the online and momentary distribution of data (audio or video). Unlike downloading, there is no content storage, but its reproduction as data is received over the internet. This means that the user, if connected to the internet, selects and listens to the desired content instead of downloading the file to his device and then playing it back.

In these current scenarios where the internet presents new formats for providing services, the State's intervention in the economy is increasingly difficult. In order to work on this issue, the research is divided into three stages. Initially, it investigates what streaming services are about, with how to analyze their legal nature in accordance with national legislation. Afterwards, the regulatory competence of the Ministry of Science, Technology, Innovation and Communication (MCTIC), the National Telecommunications Agency (Anatel) and the National Cinema Agency (Ancine) is analyzed in relation to new audiovisual content dispersion technologies.

That being said, the objective of this study is to investigate the regulatory role of the Executive Branch and regulatory agencies in the face of streaming technologies. The research methodology adopted is the hypothetical-deductive method, through which it is assumed that the MCTIC, Anatel and Ancine should exercise a regulatorysupervisory function in the face of companies providing services via streaming. The research technique used is indirect documentation, through bibliographic research.

\section{The definition and legal category of streaming services in Brazil}

The word streaming brings the idea of flow, of something that is in constant motion. In streaming services, the user pays for access to content in real time at the expense of the possibility of saving the file on devices. Thus, these services consist of online data distribution. Unlike downloads, there is no content storage, 
which is reproduced as the user receives it. ${ }^{2}$ According to Miguel Afonso Caetano, streaming should be understood as a temporary download of a file, as the complete file is not intended to be saved on the computer's hard disk. What happens is the transfer in small sections at the speed of real time, then being removed. ${ }^{3}$

In this type of service, the registered user has access to the content made available in real time instead of downloading the file on the device used, allowing better interaction between users and organization of files in lists, for example. It is a technology that allows the viewing of multimedia files (audio and/or video) directly from the internet (through the service provider) without downloading this content to the device for later viewing. ${ }^{4}$ According to Ribeiro da Cruz, streaming is a space where the user can access certain types of cultural products (such as music or videos) without having to download the executed file. ${ }^{5}$ In this sense, the product will only be executed if the user is connected to the internet and to the performing service. Furthermore, streaming is also different than progressive download, in which it is possible to play the content while a copy of the file is stored on the user's device, as is the case when receiving videos in instant communication applications such as WhatsApp. ${ }^{6}$

It is important to remember that the streaming service is provided by an operator who owns the copyright of the works or someone who licenses the distributed content. ${ }^{7}$ In practice, therefore, these services can be described as portals for consumption, promotion and circulation of audiovisual content, being able to operate as social media or in an articulated way with them. ${ }^{8}$

It is also worth mentioning that many paid streaming services allow offline access to content, that is, without internet access: the user can save, without downloading the file on his mobile device and access the content even when disconnected from the internet. It is a temporary or conditional download, as an ephemeral copy of the content is created in the memory of the device or equipment in which it will

2 FRANCISCO, Pedro Augusto P.; VALENTE, Mariana Giorgetti (Org.). Do rádio ao streaming: ECAD. Direito autoral e música no Brasil. Rio de Janeiro: Beco do Azougue, 2016, p. 267.

3 CAETANO, Miguel Afonso. Spotify e os piratas: Em busca de uma “jukebox celestial” para a diversidade cultural. Revista Crítica de Ciências Sociais, n. 109, maio 2016, p. 229-249.

4 SUÁREZ, Ana Cristina Triana; TRUJILO, Carlos Humberto Aragón. Acción 1 BEPS. Metodología aplicación en Colombia economia digital - Negocio streaming - Caso Netflix. Revista de Derecho Fiscal, n. 13, jul./ dec. 2018, p. 23-89.

5 CRUZ, Leonardo Ribeiro da. Os novos modelos de negócio da música digital e a economia da atenção. Revista Crítica de Ciências Sociais, n. 109, maio 2016, p. 203-228.

6 GALDINO, Guilherme. Streaming: ICMS-Mercadoria, ICMS-Comunicação ou ISS sobre serviço de valor adicionado? Revista Tributária e de Finanças Públicas, ano 27, v. 140, p. 83-104, jan./abr. 2019.

7 SUÁREZ, Ana Cristina Triana; TRUJILO, Carlos Humberto Aragón. Acción 1 BEPS. Metodología aplicación en Colombia economia digital - Negocio streaming - Caso Netflix. Revista de Derecho Fiscal, n. 13, jul./ dec. 2018, p. 23-89.

8 KISCHINHEVSKY, Marcelo; VICENTE, Eduardo; DE MARCHI, Leonardo. Música infinita: serviços de streaming como espaços híbridos de comunicação e consumo musical. In: Anais do Encontro Nacional da Associação Nacional de Programas de Pós-Graduação em Comunicação. 2015. Available at: https://bdpi.usp.br/single. php?_id=002735674\&locale=en_US. Accessed: 25 maio 2021. 
be accessed. ${ }^{9}$ In this threshold, Miguel Afonso Caetano warns that the distinction between streaming and download seems to reside, therefore, increasingly in an almost ontological dilemma regarding the moment or situation in which streaming becomes an effective download and vice-versa, since their contours are closer and closer thanks to the continuous advance of technology. ${ }^{10}$

It seems inevitable that the driving forces of the new digital economy are constituted by modern trust, technology and economic and cultural pressure. ${ }^{11}$ Thus, the growth and progress of streaming audiovisual content applications demonstrate that in these scenarios of innovation, technological development is directly linked to the power of the economy and eventual regulation by the Public Administration. ${ }^{12}$ In this sense, the services offered through the streaming logic provide a solution for the audiovisual industry, which is lost since the replacement of the consumption of physical disks by digital files. Once the definition of what the streaming service is and how it works, it is imperative to analyze their legal nature.

According to Ericson Meister Scorsim, internet applications are considered by the General Telecommunications Law (LGT) as "value-added services". Thus, for the author, there is no way to compare pay television services with the novel on-demand streaming service, since they do not fall under the same regulatory locus, since while the former is a telecommunications service, the second is a mere service that adds value to it. ${ }^{13}$

The author's understanding is based on the legal definition of Article 61 of the General Telecommunications Law. According to Article 60 of the General Telecommunications Law, the telecommunications service is the set of activities that enable the provision of telecommunications, which, in turn, is defined by law as "the transmission, emission or reception, by wire, radio, media optical or any other electromagnetic process, of symbols, characters, signs, writings, images, sounds or information of any nature" (Article $60, \S 1) .{ }^{14}$ However, the law also introduces to

9 LOYOLA, Renata. O streaming no mundo. In: FREITAS, Rafael Véras de; RIBEIRO, Leonardo Coelho; FEIGELSON, Bruno (Coord.). Regulação e novas tecnologias. Belo Horizonte: Fórum, 2017, p. 526.

10 CAETANO, Miguel Afonso. Spotify e os piratas: Em busca de uma “jukebox celestial” para a diversidade cultural. Revista Crítica de Ciências Sociais, n. 109, maio 2016, p. 229-249.

11 RIBEIRO, Leonardo Coelho. A instrumentalidade do direito administrativo e a regulação de novas tecnologias. In: FREITAS, Rafael Véras de; RIBEIRO, Leonardo Coelho; FEIGELSON, Bruno (Coord.). Regulação e novas tecnologias. Belo Horizonte: Fórum, 2017, p. 61-70.

12 It is worth emphasizing that the notion of development is not limited to the economic aspect. Thus, according to André Folloni, the Brazilian Constitution, while imposing economic development as its objective, also prescribes the eradication of poverty and the reduction of inequalities. See in: FOLLONI, André. A complexidade ideológica, jurídica e política do desenvolvimento sustentável e a necessidade de compreensão interdisciplinar do problema. Revista Direitos Humanos Fundamentais, Osasco, jan.jun./2014, ano 14, n. 1, p. 63-91.

13 SCORSIM, Ericson Meister. Direito das comunicações: serviços de telecomunicação (móvel pessoal e telefonia fixa), acesso à internet, TV por radiodifusão e TV por assinatura. Curitiba: edição do autor, 2016, p. 29.

14 Literal translation of: “a transmissão, emissão ou recepção, por fio, radioeletricidade, meios ópticos ou qualquer outro processo eletromagnético, de símbolos, caracteres, sinais, escritos, imagens, sons ou informações de qualquer natureza". 
the legal framework the notion of "value-added service". According to Article 61 of the LGT, this type of service is characterized as an activity that adds new utilities (referring to access, storage, presentation, movement or retrieval of information) to the telecommunications service that supports it with which it is not confused, as far as which does not constitute a telecommunication service (Article 61, §1).

Victor Oliveira Fernandes defends the same understanding. The concept of value-added services, provided for in the aforementioned Article 61 of the LGT, refer to services that generally employ information processing functions performed within telecommunications networks and, according to the author, this is what happens with streaming services, insofar as the providers of these services are characterized as simple users of the telecommunications services that support them. ${ }^{15}$

Therefore, Victor Oliveira de Fernandes joins the doctrine of Ericson Meister Scorsim by proposing that internet applications providing streaming services are, in principle, within the classification of value-added services, under the terms of Article 61 of the LGT, although this definition - according to him - is quite volatile and dependent on completion by the institutional performance of Anatel. ${ }^{16}$

The position of the aforementioned authors seems correct. On the one hand, the definition of "internet" is subject to Article 60 of the LGT as a telecommunication service. ${ }^{17}$ On the other hand, streaming service providers should be understood as value-added services to the internet, as they add utilities related to the access of audiovisual content, allow the storage of information and present new instruments for the end user of the world wide web. if they use the pre-established network. Therefore, it is understood that the services provided by on-demand audiovisual content streaming are not to be confused either with public sound or sound and image broadcasting services or with pay-TV services.

\section{The regulatory power of the Ministry of Science, Innovation, Technology and Communication}

The relationship between the State and the economy is not close (and even less predictable). It is constantly changing due to political, ideological and economic contingencies. In this way, this dynamism between the two spheres allows the Law to limit and direct - although not in its entirety - economic activity. ${ }^{18}$ And, in the

15 FERNANDES, Victor Oliveira. Regulação de serviços de internet: desafios da regulação de aplicação Over The-Top (OTT). Rio de Janeiro: Lumen Juris, 2018, p. 154.

16 FERNANDES, Victor Oliveira. Regulação de serviços de internet: desafios da regulação de aplicação OverThe-Top (OTT). Rio de Janeiro: Lumen Juris, 2018, p. 159-160.

17 This present essay defines internet as a means of telecommunications as it is a system consisting of a set of logical protocols, structured on a worldwide scale for public and unrestricted use, in order to enable data communication between terminals through different networks.

18 ARAGÃO, Alexandre Santos de. O conceito jurídico de regulação econômica. Revista de Direito Administrativo \& Constitucional. Curitiba: Juruá, n. 6, 2001, p. 64. 
post-modern context of technological advances, state intervention in the economy (through regulation) should be based, according to Alexandre Santos de Aragão, on efficient action, with consensual and flexible regulatory techniques that are more effective and less costly for the State and for society. ${ }^{19}$

The analysis starts from the attributions and competences of the Executive Power. In this sense, both the LGT and the Brazilian Telecommunications Code itself create competences for the Executive Power in the scope of the provision of sound or sound and image radio broadcasting services.

In Article 18 of Law No. 9,472 of 1997 (LGT), the Executive Branch is empowered to institute or eliminate the provision of a telecommunications service modality in the public regime, concurrently or not with its presence in the private regime, to approve the general plan of service grants in the public regime, approve the target plan for the universalization of the service provided under the public regime and authorize Brazilian companies to participate in intergovernmental organizations or consortia for the provision of telecommunications services.

Furthermore, the LGT establishes in Article 211 that it is the competence of the Executive Power to grant sound ot sound and image broadcasting services. According to the provision, Anatel is responsible for preparing and maintaining channel distribution plans (through radio frequencies), which must also consider aspects related to technological evolution. The sole paragraph of the article provides that the agency must also oversee the technical aspects of radio frequency stations. In this sense, although LGT's device is silent, Marcelo Barros da Cunha understands that the authority to oversee other legal, regulatory and contractual obligations of broadcasters is the responsibility of the Ministry of Science, Technology, Innovation and Communications (MCTIC). ${ }^{20}$

In addition to the service granting activity, carried out by the Ministry, it is up to the interested parties to request to the MCTIC (i) the renewal of the grant, direct transfer or registration of contractual and statutory changes for grants already granted; (ii) the receipt of the Federal Government's consignment for the execution of sound, sound and image radio broadcasting services or television retransmission; (iii) the receipt of a community broadcasting grant; (iv) the receipt of educational broadcasting grants; (v) the receipt of a TV retransmitter grant; (vi) the receipt of a concession for commercial broadcasting services; among others. ${ }^{21}$

19 ARAGÃO, Alexandre Santos de. O conceito jurídico de regulação econômica. Revista de Direito Administrativo \& Constitucional. Curitiba: Juruá, n. 6, 2001, p. 68.

20 CUNHA, Marcelo Barros. Regulação da radiodifusão no Brasil: uma crítica à luz do pluralismo e do direito à comunicação. Rio de Janeiro: Lumen Juris, 2018, p. 62.

21 See in: BRASIL. Ministério da Ciência, Tecnologia, Inovações e Comunicações. Comunicações. Available at: http://www.mctic.gov. br/mctic/opencms/comunicacao/index.html. Accessed: 07 dez. 2020. 
The competence of the Executive Power to grant the broadcasting services provided for in the LGT results from the discipline of the Brazilian Telecommunications Code. The legislation of the 60s affirms that the Executive Branch - currently a competence of the MCTIC - will be competent to publish the notice for the realization of new concessions or permissions for public broadcasting services, as the grant is the prerogative of the President of the Republic. ${ }^{22}$

It can be seen, therefore, that the powers of the Executive Branch, whose activities are carried out by the MCTIC, demonstrate that the focus of action is the organization and structuring of the provision of broadcasting services. Interference, therefore, takes place only within the scope of this public service. However, the audiovisual sector is not restricted to broadcasting services. On the contrary, most of the sector regulated by the Public Power involves the provision of economic activities by market agents. For this reason, it is relevant to study the performance of Anatel and Ancine as regulatory agencies responsible for the audiovisual market in Brazil.

\section{The competence of the National Telecommunications Agency}

Sérgio Guerra discusses the fine line between private services and the challenges that new technologies present to the regulatory state, in which the pragmatic case is that of telecommunications. According to the author, in normative terms, economic relations have two considerations: on the one hand, the constitutional principles of national sovereignty, social function of property, freedom of initiative, free competition, consumer protection, reduction of regional inequalities and social, repression of abuse of economic power and continuity of public service (provided under public law); on the other hand, when provided under private law, telecommunications services must be based on the principle of free, broad and fair competition among all providers. ${ }^{23}$

In the context of telecommunications, the regulatory agency competent in the National Telecommunications Agency (Anatel). It was instituted by Law n. 9.472 of 1997 and regulated by Decree n. 2.338 of 1997 . For Leila Cuéllar, the legislation that creates Anatel is one of the most complete in the sphere of regulatory agencies. Nevertheless, the author emphasizes that the creation of the special autarchy

22 Article 34. New concessions or permissions for the broadcasting service shall be preceded by a notice, published sixty days in advance by the competent body of the Executive Branch, inviting interested entities to present their proposals within a specified period. $\S 1$ The granting of the concession or permission is the prerogative of the President of the Republic, after hearing the competent body of the Executive Power on the proposals and requirements required by the notice and publishing the respective opinion (...). Literal translation of Article 34 from the Law n. 9.472/97.

23 GUERRA, Sérgio. Discricionariedade, regulação e reflexividade: uma nova teoria sobre as escolhas administrativas. Prefácio de Tercio Sampaio Ferraz Junior. 4. ed., revista e atualizada. Belo Horizonte: Fórum, 2017, p. 147. 
provided for the creation of the regulatory framework for the telecommunications sector before the eventual privatization measure. ${ }^{24}$

Anatel's competences are described in Article 19 of the LGT and involve the adoption of measures to serve the public interest and for the development of telecommunications at the national level. Therefore, it is up to the regulatory agency to promote the development of telecommunications in order to provide a modern and efficient structure, capable of offering society adequate, varied and affordable services throughout the national territory.

Among the attributions given by the LGT, there is the need to act in the sense of implementing the national telecommunications policy (inc. I), to represent Brazil in international telecommunications organizations (inc. II), to issue norms regarding the granting of services is highlighted of telecommunications in the public regime (inc. IV) and to provide these services in the private regime (inc. X), to regulate the standards of the equipment used by telecommunications service providers (inc. XII), to issue norms that ensure compatibility, the integrated operation and the interconnection between the networks (inc. XIV) as a way to guarantee competition in the sector, exercise the function of control, prevention and repression of infringements of the economic order in the sector in the field that it is responsible for (inc. XVIII) and to reassess, periodically, the regulation due to the promotion of competition in the telecommunications market and technological evolution (inc. XXXII).

The agency is also responsible for ensuring and ensuring the right of use - by interested agents - of telecommunications service networks for the provision of value-added services, as well as regulating the conditions and relationship of this interaction between the service provider and the owner of the infrastructure telecommunications (Article 61, §2). Under the public regime for the provision of telecommunications services, the agency is responsible for regulating the obligations of universalization and continuity of service (Article 79), the prior granting through a concession for the exploitation of the public telecommunications service (Article 83), and it is also within its competence to carry out the bidding for the granting of said concession (Article 89).

Overall, the legislation establishing Anatel ensures that the regulatory agency is responsible for overseeing the concession contract (permit or authorization, depending on the LGT's disposition) of telecommunications services, establishing prerogatives that allow the agency to intervene in sector administrative contracts in order to guarantee the continuity of the service and the preservation of the infrastructure necessary for its provision.

24 CUÉLLAR, Leila. Introdução às agências reguladoras brasileiras. Belo Horizonte: Fórum, 2008. (Coleção luso-brasileira de direito público, 2), p. 116. 
In this scenario, Law n. 12.485 of 2011 reiterates a series of competences of Anatel that relate to the infrastructure of the telecommunications network. The agency is responsible for regulating and inspecting the content distribution activity by the conditional access service providers (which is considered a telecommunications service) even though it is not a public service. In fact, interested companies must observe the agency's edict regulation for the provision of the service. Examples of Anatel's performance in this sector are Resolution n. 411 of 2005 and Resolution n. 581 of 2012, which approve, respectively, the General Quality Plan for pay-television services and the Regulation of Conditional Access Service, to be observed by all economic actors that provide the service, regardless of the technology used. Furthermore, Resolution n. 717 of 2015, which, more broadly in the sector, approves the Regulation on the Quality of Telecommunications Services, must also be observed by all economic actors providing telecommunications services (STFC, SMP, SCM and SeAC). ${ }^{25}$

Thus, it is concluded that Anatel is responsible for maintaining the telecommunications networks, regulating and inspecting the use of these networks for the provision of services and guarantee, through the issuance of resolutions and other normative acts within its competence, continuity - related to technical issues - of these services. Therefore, since telecommunications services do not comprise the services provided by applications accessed through the internet, Anatel is incompetent to carry out the granting and inspection of internet applications and, consequently, the provision of audiovisual content by streaming does not falls within the competence of the agency. In view of the different legal nature of telecommunications and value-added services, the legislation so far does not allow streaming service providers to be subject to Anatel's regulation. ${ }^{26}$ Therefore, these are oblivious to Anatel's exercise of regulatory power. The agency may only interfere in the performance of value-added service providers to regulate the conditions and

25 BRASIL. Agência Nacional de Telecomunicações (Anatel). Resolução no 411, de 14 de julho de 2005. Aprova o Plano Geral de Metas de Qualidade para os serviços de televisão por assinatura (PGMQ - televisão por assinatura). Available at: https://www.Anatel.gov.br/legislacao/resolucoes/20-2005/141-resolucao-411. Accessed: 30 apr. 2021; BRASIL. Agência Nacional de Telecomunicações (Anatel). Resolução no 581 , de 26 de março de 2012. Aprova o Regulamento do Serviço de Acesso Condicionado (SeAC), bem como a prestação do Serviço de TV a Cabo (TVC), do Serviço de Distribuição de Sinais Multiponto Multicanal (MMDS), do Serviço de Distribuição de Sinais de Televisão e de Áudio por Assinatura via Satélite (DTH) e do Serviço Especial de Televisão por Assinatura (TVA). Available at: https://www.Anatel.gov.br/ legislacao/resolucoes/2012/139-resolucao-581. Accessed: 30 apr. 2021; BRASIL. Agência Nacional de Telecomunicações (Anatel). Resolução no 717, de 23 de dezembro de 2019. Aprova o Regulamento de Qualidade dos Serviços de Telecomunicações - RQUAL. Available at: http://www.in.gov.br/web/dou/-/ resolucao-n-717-de-23-de-dezembro-de-2019-235328441. Accessed: 26 jun. 2021.

26 Nesse sentido: SCORSIM, Ericson Meister. Direito das comunicações: serviços de telecomunicação (móvel pessoal e telefonia fixa), acesso à internet, TV por radiodifusão e TV por assinatura. Curitiba: Edição do autor, 2016, p. 100-102. 
the relationship between the value-added services and the telecommunications networks, pursuant to the aforementioned Article 61, §2, of the LGT. ${ }^{27}$

However, the doctrine differs in relation to Anatel's competence. Sérgio Guerra, studying disruptive innovations in the telecommunications sector, states that the classic public/private dichotomy naturally leads to regulatory asymmetry. As a result, the jurist maintains that this tight division between the services provided under the private and public regime is no longer sufficient for the regulation of the telecommunications sector. Thus, he concludes that the Public Administration must act to correct the effects of imperfect competition and the repression of the economic order in the sector, in order to promote competition. Therefore, for the author, it is up to Anatel to adopt asymmetric regulatory measures (in a broad sense) to balance the telecommunications market. ${ }^{28}$

\section{The sectorial role of the Nacional Cinema Agency}

To Ancine, created by Provisional Measure n. 2.228-1 of 2001 and regulated by Decree n. 8.283/14, was assigned the activities of development, regulation and inspection of the film and videophonographic industry in the country, according to article 5 of the norm that instituted the regulatory agency. Furthermore, the reading of the items in article 7 of the Provisional Measure allows us to conclude that the agency is responsible for the entire Brazilian audiovisual market, without segregation of any segment.

Article 7 . Ancine will have the following competences: (...)

II - oversee compliance with legislation relating to national and foreign cinematographic and videophonographic activity in the various market segments, in accordance with the regulation; (...)

$\mathrm{V}$ - regulate, in accordance with the law, the activities of promotion and protection of the national cinematographic and videophonographic industry, safeguarding the free expression of thought, creation, expression and information; (...)

XIII - provide Certificates of Registration for production, co-production, distribution, licensing, assignment of exploration, broadcasting and exhibition rights of cinematographic and videophonographic works; (...)

27 FERNANDES, Victor Oliveira. Regulação de serviços de internet: desafios da regulação de aplicação OverThe-Top (OTT). Rio de Janeiro: Lumen Juris, 2018, p. 160.

28 GUERRA, Sérgio. Discricionariedade, regulação e reflexividade: uma nova teoria sobre as escolhas administrativas. Prefácio de Tercio Sampaio Ferraz Junior. 4. ed. revista e atualizada. Belo Horizonte: Fórum, 2017, p. 147-148. 
XIV - to manage the information system for monitoring the activities of the film and videophonographic industry in its various means of production, distribution, exhibition and dissemination (...). ${ }^{29}$ (emphasis added)

Based on this article, it is concluded that the promotion, regulation and inspection activities of Ancine will fall on all companies that provide production, distribution, licensing, broadcasting and exhibition services of cinematographic and videophonographic content, regardless of the market segment in which the actors economics are involved.

However, article 7, item XVIII, presents an exception, based on the competences also provided for in Law n. 12.485 of 2011 . According to the provision, Ancine is responsible for regulating and inspecting the programming and packaging activities of companies providing Conditional Access Services, pursuant to Law n. 12.485 of 2011. Among the attributions that are incumbent on Ancine, the need for accreditation of the programming with the regulatory agency, the possible collection of a fine in the event of the company's failure to offer a device that allows blocking the reception of content that is not recommended for the a certain age group (it is also the company's duty to inform the indicative classification of the program), the verification and inspection of due compliance with the minimum national content standards that must be offered in the programming schedule and the regulation on the setting of prime time for Conditional Access Services.

The depth of the analysis carried out by Ancine in relation to the Brazilian audiovisual can be verified from the provisions of articles 18 and 19 of MP n. 2.228-1 of 2001. Under Article 18, companies that distribute and produce audiovisual works for the subscription-based mass electronic communication services market segment, as well as programmers in other market segments and home video rental companies and companies displaying such content they must provide the agency with reports on the supply and consumption of audiovisual works by the public, in addition to the revenues that this exploitation of the market has earned for the company. In Article 19 , the concern turns to video distributors and rental companies, as companies

29 Literal translation of: “Article 7ㅇ․ A Ancine terá as seguintes competências: (...)

II - fiscalizar o cumprimento da legislação referente à atividade cinematográfica e videofonográfica nacional e estrangeira nos diversos segmentos de mercados, na forma do regulamento; (...)

V - regular, na forma da lei, as atividades de fomento e proteção à indústria cinematográfica e videofonográfica nacional, resguardando a livre manifestação do pensamento, da criação, da expressão e da informação; (...) XIII - fornecer Certificados de Registro dos contratos de produção, coprodução, distribuição, licenciamento, cessão de direitos de exploração, veiculação e exibição de obras cinematográficas e videofonográficas; (...) XIV - gerir o sistema de informações para o monitoramento das atividades da indústria cinematográfica e videofonográfica nos seus diversos meios de produção, distribuição, exibição e difusão (...)" (emphasis added). 
must issue a biannual report describing the number of national and foreign works distributed, as well as the number of copies per title.

It should also be noted that companies producing, distributing, exhibiting national or foreign cinematographic and videophonographic works must register with Ancine (Article 22). In fact, it is only with this registration that companies can and benefit from public resources or tax incentives for the cinematographic or videophonographic activity (Article 22, sole paragraph). Nevertheless, the MP still determines that the contracting of commercial exploration, licensing, production, co-production, exhibition, distribution, commercialization, import and export rights of cinematographic and videophonographic works, regardless of the support or market vehicle used for transmission, shall be informed to Ancine prior to its exhibition and with proof of payment from Condecine (Article 29). It is also the agency's responsibility to receive the amounts related to the payment of the Condecine (Article 36). ${ }^{30}$

Furthermore, it is important to highlight the Brazilian Observatory of Cinema and Audiovisual (OCA), created in December 2008 and integrated within Ancine's scope of action. The objective of the observatory is the dissemination of qualified data and information produced by the regulatory agency. Thus, its performance is in line with Ancine's strategic objective of improving the generation and dissemination of knowledge in the audiovisual sector. The data obtained by the OCA are the result of the agency's development, regulation and inspection work, in accordance with its legal competences. OCA's work involves the analysis of the Brazilian audiovisual market (obtaining indicators of audiovisual market activities in exhibition halls, television and other media), cinema (box office data, distribution, exhibition park, production and international co-production), television (information on open and pay television, such as channel programming and packaging) and other media (information on video on demand, home video, and feature film screening windows). ${ }^{31}$

It should be noted, therefore, that, unlike Anatel, which will be responsible for regulating the infrastructure of the electronic networks that serve as a basis for the

30 Literal translation of: “Article 36. CONDECINE shall be collected from ANCINE, in the form of the regulation: $\mathrm{I}$ - on the date of registration of the title for the exhibition rooms and home video markets in any support, and electronic mass communication services by subscription for the programmers referred to in item XV of Article 1 of Provisional Measure n. 2.228-1, of September 6, 2001, in any support, as per Annex I; II - on the date of registration of the title for the sound and image broadcasting services market and other markets, as per Annex I; III - on the date of registration of the title or up to the first business day following its request, for Brazilian, Brazilian cinematographic or videophonographic advertising work filmed abroad or abroad for each market segment, as per Annex I; IV - on the date of registration of the title, for the sound and image broadcasting and electronic mass communication services market by subscription, for national cinematographic and videophonographic work, as per Annex I; V - on the date of payment, credit, employment or remittance of the amounts referred to in the sole paragraph of Article 32; $\mathrm{VI}$ - on the date of granting the rating certificate, in other cases, as per Annex I; VII - annually, until March 31, for the services referred to in item II of Article 32 of this Provisional Measure".

31 BRASIL. Observatório Brasileiro do Cinema e do Audiovisual (OCA). Agência Nacional do Cinema (Ancine). Available at: https://oca.ancine.gov.br/sobre-o-oca. Accessed: 23 may 2021. 
issuance and distribution of audiovisual content, Ancine's regulation is concerned with the activities of production, licensing, exploration and dissemination of content. However, sometimes, under the law, joint competences of the two agencies are verified. An example is the activity of regulation and inspection, even within the scope of its own powers, to define the joint collection of the Condecine portion (Article 38, §2 of MP n. 2.228-1 of 2001). ${ }^{32}$

On the competence of the regulatory agencies studied regarding the provision of streaming services, Guilherme Siqueira Vieira, when debating the service operated by Netflix (a streaming service), states that the impositions made by the regulatory agencies on other telecommunications or production, programming, packaging and distribution companies they cannot fall on the audiovisual service provided by the company. This is because, for the author, neither Anatel nor Ancine is responsible for regulating these services, since any act of administrative police of these - through sanction or fine - would be an illegal act, without any legal or legal basis for such. ${ }^{33}$ However, it seems that this position is not correct and it will not be adopted in the present study.

Based on the analysis of legislation in the telecommunications sector in Brazil, as well as in relation to the competences of regulatory agencies, with regard to Anatel, it is understood that it is not really the agency's responsibility to regulate and supervise production, programming, activities, packaging (in the form of catalogues) and distribution of content provided by streaming service providers due to the legal nature of the service. As it is an value-added service and not a telecommunication service, the powers given by LGT to Anatel do not apply, with the exception of the discipline of Article $61, \S 2$, which makes the agency competent to ensure the right to use the networks by internet applications, and may even regulate the relationship between the value-added services and the telecommunications service providers with regard to the use of the network.

Nonetheless, the analysis of the legislative framework that governs and empowers Ancine allows the agency to act with the purpose of promoting, regulating and supervising the cinematographic and videophonographic industry in the various market segments. In this sense, and not questioning that the activity of production, programming, packaging (in the form of catalogues) and distribution of audiovisual

32 Article 38. The administration of CONDECINE, including the activities of collection, taxation and inspection, is responsible for: (...) §2 Ancine and the National Telecommunications Agency - Anatel shall carry out regulatory and inspection activities within the scope of their powers and may define the joint payment of the portion of the Condecine due referring to item III of the caput of Article 33 and the inspection fees referred to in Law n. 5.070, of July 7, 1966, which creates the Telecommunications Inspection Fund. (Included by Law n. 12.485 of 2011). Literal translation of Article 34 from the Law n. 9.472/97.

33 VIEIRA, Guilherme Siqueira. A regulação dos novos serviços on-line no Brasil: o caso Netflix versus ANCINE e ANATEL. In: BONAT, Alan Luiz; NASCIMENTO NETO, José Osório do; QUETES, Regeane Bransin (Coord.) Políticas públicas e desenvolvimento. Curitiba: Îthala, 2016, p. 239. 
content involves the recording of images and sounds in the form of videophonograms, it is understood that, according to Brazilian legislation, Ancine's performance may also fall on the streaming services sector. It should be noted that the Provisional Measure that instituted Ancine allows for a comprehensive action by the agency in the audiovisual sector and, insofar as streaming applications are considered economic activities in this market, the intervention of the regulatory agency has a legal basis.

Therefore, it seems reasonable to say that Ancine's competence encompasses all on-demand streaming services, even those that only provide sound content. This is due to technological advances, as nothing prevents the future use of music streaming platforms for the provision of video content. And, in this case, the non-coverage of the service may result in a new regulatory burden. For this, however, since the agency is not competent to regulate, supervise and promote the phonographic industry, a legislative reform is needed to allow Ancine to work in the sector.

\section{Conclusion}

When debating the regulation of new technologies, it is important to remember that the regulation of disruptive innovations, in addition to recognition, brings security for activities to be developed under the protection of law. ${ }^{34} \mathrm{~A}$ regulation guided by the logic of confrontation with the innovative sector or based on unilateral state regulatory solutions is not promising, since technological development will find ways to unfold from the applied regulation.

The future of disruptive innovations is unpredictable and Public Administration must reinvent itself. And this change involves the instrumentalist role of Administrative Law. In the scope of audiovisual streaming, the separation between the disruptive models of audiovisual content diffusion is even more evident as technology advances. And this requires a new regulatory action by the State.

It is concluded that the adaptation of new technologies to the regulations of the regulated sector is not enough in itself, and it must also rely on the adaptation of legislation to disruptive innovations in order to allow a competitive environment between market players with a view to developing the audiovisual sector in Brazil. Thus, the normative treatment of streaming must be concerned with allowing the harmonious coexistence of law and technology.

It is up to the Public Administration, therefore, the task of reconciling public and private interests in favor of a regulation that allows the development of the national audiovisual sector and guarantees freedom of initiative in this market, according

34 BAPTISTA, Patricia; KELLER, Clara Iglesias. Por que, como e quando regular as novas tecnologias? Os desafios trazidos pelas inovações disruptivas. RDA - Revista de Direito Administrativo, Rio de Janeiro, v. 273, p. 123-163, set./dez. 2016. 
to the bases established by the legislator and regulatory agencies. In this sense, the actions of the National Telecommunications Agency and the National Cinema Agency are essential.

\section{References}

ARAGÃO, Alexandre Santos de. O conceito jurídico de regulação econômica. Revista de Direito Administrativo \& Constitucional. Curitiba: Juruá, n. 6, 2001. p. 59-74.

BAPTISTA, Patricia; KELLER, Clara Iglesias. Por que, como e quando regular as novas tecnologias? Os desafios trazidos pelas inovações disruptivas. RDA - Revista de Direito Administrativo. Rio de Janeiro, v. 273, p. 123-163, set./dez. 2016.

BRASIL. Ministério da Ciência, Tecnologia, Inovações e Comunicações. Comunicações. Available at: http://www.mctic.gov. br/mctic/opencms/comunicacao/index.html. Accessed: 07 dez. 2020.

BRASIL. Observatório Brasileiro do Cinema e do Audiovisual (OCA). Agência Nacional do Cinema (Ancine). Available at: https://oca.ancine.gov.br/sobre-o-oca. Accessed: 23 may 2021.

CAETANO, Miguel Afonso. Spotify e os piratas: Em busca de uma "jukebox celestial" para a diversidade cultural. Revista Crítica de Ciências Sociais, n. 109, maio 2016, p. 229-249.

CHRISTENSEN, Clayton M.; RAYNOR, Michael E. Innovator's solution: creating and sustaining successful. Boston: Harvard Business School Press, 2003.

CRUZ, Leonardo Ribeiro da. Os novos modelos de negócio da música digital e a economia da atenção. Revista Crítica de Ciências Sociais, n. 109, maio 2016, p. 203-229.

CUÉLLAR, Leila. Introdução às agências reguladoras brasileiras. Belo Horizonte: Fórum, 2008. (Coleção luso-brasileira de direito público, 2).

CUNHA, Marcelo Barros. Regulação da radiodifusão no Brasil: uma crítica à luz do pluralismo e do direito à comunicação. Rio de Janeiro: Lumen Juris, 2018.

FERNANDES, Victor Oliveira. Regulação de serviços de internet: desafios da regulação de aplicação Over-The-Top (OTT). Rio de Janeiro: Lumen Juris, 2018.

FERRAZ JR., Tércio Sampaio. Introdução ao estudo do direito: técnica, decisão, dominação. São Paulo: Atlas, 2010.

FOLLONI, André. A complexidade ideológica, jurídica e política do desenvolvimento sustentável e a necessidade de compreensão interdisciplinar do problema. Revista Direitos Humanos Fundamentais, Osasco, jan.jun./2014, ano 14, n. 1, p. 63-91.

FRANCISCO, Pedro Augusto P.; VALENTE, Mariana Giorgetti (Org.). Do rádio ao streaming: ECAD, Direito autoral e música no Brasil. Rio de Janeiro: Beco do Azougue, 2016.

GALDINO, Guilherme. Streaming: ICMS-Mercadoria, ICMS-Comunicação ou ISS sobre serviço de valor adicionado? Revista Tributária e de Finanças Públicas, ano 27, v. 140, p. 83-104, jan./ abr. 2019.

GUERRA, Sérgio. Discricionariedade, regulação e reflexividade: uma nova teoria sobre as escolhas administrativas. Prefácio de Tercio Sampaio Ferraz Junior. 4a ed. revista e atualizada. Belo Horizonte: Fórum, 2017.

KISCHINHEVSKY, Marcelo; VICENTE, Eduardo; MARCHI, Leonardo De. Em busca da música infinita: os serviços de streaming e os conflitos de interesse no mercado de conteúdos digitais. Revista Fronteiras - Estudos Midiáticos, v. 17, n. 3, p. 302-311, setembro/dezembro 2015. 
LOYOLA, Renata. O streaming no mundo. In: FREITAS, Rafael Véras de; RIBEIRO, Leonardo Coelho; FEIGELSON, Bruno (Coord.). Regulação e novas tecnologias. Belo Horizonte: Fórum, 2017.

LUHMANN, Niklas. Sociologia do Direito. Vol. I. Tradução: Gustavo Bayer. Rio de Janeiro: Tempo Brasileiro, 1983.

LUHMANN, Niklas. Sistemas Sociales: Lineamentos para una teoría general. Tradução: Silvia Pappe e Brunhilde Erker. México: Anthropos Editorial/Universidad Iberoamericana, 1998.

LUHMANN, Niklas. Introdução à teoria dos sistemas. 3a ed. Petrópolis: Vozes, 2009.

MARQUES NETO, Floriano de Azevedo; FREITAS, Rafael Véras de. Uber, WhatsApp, Netflix: os novos quadrantes da publicatio e da assimetria regulatória. In: FREITAS, Rafael Véras de; RIBEIRO, Leonardo Coelho; FEIGELSON, Bruno (Coord.). Regulação e novas tecnologias. Belo Horizonte: Fórum, 2017. p. 17-48.

RIBEIRO, Leonardo Coelho. A instrumentalidade do direito administrativo e a regulação de novas tecnologias disruptivas. In: FREITAS, Rafael Véras de; RIBEIRO, Leonardo Coelho; FEIGELSON, Bruno (Coord.). Regulação e novas tecnologias. Belo Horizonte: Fórum, 2017. p. 61-82.

SCORSIM, Ericson Meister. Direito das comunicações: serviços de telecomunicação (móvel pessoal e telefonia fixa), acesso à internet, TV por radiodifusão e TV por assinatura. Curitiba: Edição do autor, 2016.

SUÁREZ, Ana Cristina Triana; TRUJILO, Carlos Humberto Aragón. Acción 1 BEPS. Metodología aplicación en Colombia economia digital - Negocio streaming - Caso Netflix. Revista de Derecho Fiscal, n. 13, jul./dec. 2018, p. 23-89.

VIEIRA, Guilherme Siqueira. A regulação dos novos serviços on-line no Brasil: o caso Netflix versus ANCINE e ANATEL. In: BONAT, Alan Luiz; NASCIMENTO NETO, José Osório do; QUETES, Regeane Bransin (Coord.). Políticas públicas e desenvolvimento. Curitiba: Íthala, 2016.

Informação bibliográfica deste texto, conforme a NBR 6023:2018 da Associação Brasileira de Normas Técnicas (ABNT):

SAIKALI, Lucas Bossoni. Competence to regulate streaming in Brazil: an analysis of the roles of the Ministry of Science, Innovation, Technology and Communication, Anatel and Ancine. International Journal of Digital Law, Belo Horizonte, ano 2, n. 2, p. 119-135, maio/ago. 2021. 